\title{
Erratum to: France: A Late-Comer to Government-Nonprofit Partnership
}

\section{Edith Archambault ${ }^{1,2}$}

\section{Erratum to: Voluntas (2015) 26:2283-2310 DOI 10.1007/s11266-015-9644-5}

An affiliation should be added to the author of this paper: National Research University Higher School of Economics, Moscow, Russian Federation.

The online version of the original article can be found under doi:10.1007/s11266-015-9644-5.

$\triangle$ Edith Archambault

Edith.Archambault@univ-paris1.fr

1 University of Paris1, Center of Economics of Sorbonne (CES), Paris, France

2 National Research University Higher School of Economics, Moscow, Russian Federation 